\title{
THE NEW UNWRITTEN CONSTITUTION
}

\author{
JED RUBENFELD $\dagger$
}

\section{INTRODUCTION}

Americans do not know what to think about unwritten constitutional law. On the one hand, we know we have it, and we have had it for a very long time. Unwritten constitutional law did not begin with Roe v. Wade. ${ }^{1}$ From the very beginning, American judges have been prepared to enforce constitutional rights that cannot fairly be said to derive from any enumerated textual guarantee. ${ }^{2}$ The Framers themselves, we are told, understood constitutional rights im unwritten, natural-law terms, drawing on the English lex non scripta and "ancient constitution" traditions ${ }^{4}$ passed down to them by Blackstone and

Copyright $\odot 2001$ by Jed Rubenfeld.

$\doteqdot$ Robert R. Slaughter Professor of Law, Yale Law School. This Essay is based on a paper presented at the Constitution in Exile conference hosted by the Program in Public Law at Duke University School of Law on October 5-7, 2000.

1. 410 U.S. 113 (1973).

2. For very early examples, see Fletcher v. Peck, 10 U.S. (6 Cranch) 87,139 (1810) (opinion of Marshall, $\mathrm{CJ}$.) (establishing that there are limits to state powers that do not specifically appear in the Constitution); the fanous natural-law passages of Justice Chase's opinion in Calder v. Bull, 3 U.S. (3 Dall.) 386, 387-88 (1798) (opinion of Chase, J.) (holding a Connecticut law not invalid under the ex post facto language of the Constitution); and Vanhome's Lessee v. Dorrance, 2 U.S. (2 Dall.) 304, 311-12 (C.C.D. Pa. 1795) (opinion of Patterson, J.) (finding the Pennsylvania Confirming Act unconstitutional as it was beyond the power of the legislature). See also 2 RONALD D. Rotunda \& JOHN E. NOVAK, TREATISE ON CONSTTUTIONAL Law: SUBSTANCE AND PROCEDURE § 15.7, at 626 (3d ed. 1999) ("Despite claims to the contrary, there has never been a period of time wherein the Court did not actively enforce values which a majority of the Justices felt were essential in our society even though they had no specific textual basis in the Coustitution.").

3. See, e.g., Thomas Grey, Origins of the Unwritten Constitution: Fundamental Law in American Revolutionary Thought, 30 STAN. L. REV. 843, 893 (1978) (analyzing the development of unwritten fundamental law in revolutionary America); Suzanna Sherry, The Founders' Unwritten Constitution, 54 U. CHI. L. REV. 1127, 1164-65 (1987) ("All of these men clearly thought that certain rights existed whether or not they were declared.").

4. On the English tradition of unwritten law, which married the idea of an "ancient" constitution with that of immemorial, customary common law, both understood as lex non seripta (unwritten law), see J.G.A. POCOCK, THE ANCIENT CONSTITUTION AND THE FEUDAL LAW: A STUDY OF ENGLISH HISTORICAL THOUGHT IN THE SEVENTEENTH CENTURY 302 (1957). These 
others. ${ }^{5}$ Further, since at least 1890, when Christopher Tiedeman published his influential book on the subject, Americans have formulated their own distinctive idea of an "unwritten Constitution," neither natural nor immemorial, in which unenumerated constitutional rights are supposed to express the fundamental values or ethos of the hiving citizenry. ${ }^{6}$

On the other hand, there is an equally strong countervailing tradition opposing the idea of unwritten law. Long before legal positivism, Bracton wrote that "law derives from nothing unwritten," and it always has been possible to view America's written Constitution as a renunciation of the lex non scripta tradition. Early American judges proudly distinguished our system from England's on just this ground;

ideas were in play not only in England, but throughout sixteenth- and seventeenth-century European legal thought, often deployed to justify the concept of fundamental rights unalterable even by the king himself. See, e.g., Michael W. McConnell, Tradition and Constitutionalism Before the Constifution, 1998 U. ILL. L. REV. 173, 185 (explaiming how European scholars argued that custom was the most fundamental of laws).

5. Blackstone referred to the common law as lex non scripta. 1 WILLIAM BLACKSTONE, COMMENTARIES *17, *63; see also MATTHEW HALE, THE HISTORY OF THE COMMON LAW OF ENGLAND 22-23 (3d ed. 1739). Blackstone also identified the common law with natural-law principles, and made explicit reference to the supreme authority of natural law. 1 BLACKSTONE, supra, at *39-*44. But Blackstone was notoriously equivocal on the latter point (he also asserted the doctrine of parhamentary sovereignty, e.g., $i d$. at *91), and it is possible of course to believe in a natural law of supreme moral authority while also being a positivist with respect to legal authority. See Thomas B. McAffee, Prolegomena to a Meaningfitl Debate of the "Unwritten Constitution" Thesis, 61 U. CIN. L. REV. 107, 116-18 (1992) (examining the significant tensions that exist within the works of scholarly proponents of the unwritten constitution thesis).

6. See CHRISTOPHER G. TIEDEMAN, THE UNWRITTEN CONSTITUTION OF THE UNITED STATES: A PHILOSOPHICAL INQUIRY INTO THE FUNDAMENTALS OF AMERICAN CONSTITUTIONAL LAW 150-51, 154 (1890) (noting that "since under a popular government governmental authority rests upon the voice of the people," the "judge ... who would interpret the law rightly... need not concern himself so much with the intentions of the framers of the Constitution," but must "follow, and give effect to, the present intentions and meaning of the people"). For modern accounts, see ROBERT POST, CONSTITUTIONAL DOMAINS: DEMOCRACY, COMMUNITY, MANAGEMENT 35-44 (1995) (linking "'extra-[d]ocumentary"” constitutional law and Roe $v$. Wade with the idea of a judicial effort to speak for a contemporary "national ethos"); Paul Brest, The Misconceived Quest for Original Understanding, 60 B.U. L. REV. 204, 228-29 (1980) (discussing the importance of being able to modify precedent in Anglo-American conlmon law).

7. 2 BRACTON DE LEGIBUS ET CONSUETUDINIBUS ANGLIAE [BRACTON ON THE LAWS AND CUSTOMS OF ENGLAND] 19 (George E. Woodbine ed. \& Samuel F. Thorne trans., 1968).

8. See, e.g., Vanhorne's Lessee v. Dorrance, 2 U.S. (2 Dall.) 304, 308 (C.C.D. Pa. 1795) ("[I]n England there is no written constitution, no fundamental law, nothing visible, nothing real, nothing certain, by which a statute can be tested. In America the case is widely different ....") (emphasis added). 
occasionally, they expressly denied the legal validity of natural rights." Today, of course, the very notion of "natural law" can "sound] silly to the modern ear," and for many the idea of an unwritten constitution, witl judges speaking for the living citizenry, sounds like open season on democracy. ${ }^{11}$ But even if one sought to embrace (with spectacular indifference to reality and despite the hurdle presented by the Nintl Amendinent) the proposition that unwritten law has no legitimate role under our Constitution, one would have to acknowledge that the Constitution nowhere says so. And that acknowledgement would inean that this no-unwritten-law proposition would be nothing other tlian a proposition of unwritten constitutional law.

What really needs to be done here is to disaggregate the umbrella concept of unwritten constitutional law. Overwhelmingly, the voluminous debate on this subject has concerned the existence and legitimacy of unwritten constitutional rights, with the paradigm case being, say, Roe v. Wade; I will call this the old unwritten law.

Today, however, a very different kind of unwritten law has begun to play an increasingly salient role in the Supreme Court's constitutional decisions. This new unwritten law sometimes figures in cases dealing with unenumerated rights, but it also figures in cases dealing with textually explicit guarantees. The new unwritten constitutional law is more unwritten than anything in Roe, so unwritten that no one lias written about it yet-so unwritten, in fact, that it does not even appear in the very decisions where it does its work.

Readers will think I am joking. Well, perhaps so. But what I have just said is literally true, as I will try to show in what follows.

\section{THE OLD UNWRITTEN LAW}

This Essay was written for a conference on the topic of whether we are today in the middle of a fundamental regime change in consti-

9. The famous example is of course also from Calder v. Bull, 3 U.S. (3 Dall.) 386 (1798). See id. at 399 (Iredell, J., concurring) ("If ... the Legislature ... shall pass a law, within the general scope of their constitutional power, the Court cannot pronounce it to be void, merely because it is, in their judgment, contrary to the principles of natural justice.").

10. McConnell, supra note 4, at 184 .

11. See, e.g., ROBERT BORK, THE TEMPTING OF AMERICA: THE POLITICAL SEduction OF THE LAW 1-11 (1990) (arguing that political temptations lure judges aray from strictly adhering to their role as it is defined in the Constitution); Henry Monaghan, In Celebration of the Bicentennial of the Constitution: Comment on Professor Van Alstyne's Paper, 72 IOWA L. REv. $1309,1309-10$ (1987) (suggesting that "perhaps a majority of judges and commentators have long ago abandoned 'this Constitution"). 
tutional law. Within this topic, the subject of unwritten law raises two very different questions. The first is familiar. It asks whether the old style of unwritten law-meaning, roughly, unenumerated constitutional rights, of the sort typified by Roe's right of privacy-which some identify with the Warren or Brennan Court, still flourishes in the present Court's constitutional decisions.

The question may not be terribly interesting, but it is a fair one, given the express efforts by Justices in the currently dominant majority to portray themselves as textuahists. Examples of this reinvigorated textuahisin would include the Lopez case, in which the Court reasserted the significance of the word "commerce" in Article I, Section $8 ;^{12}$ the City of Boerne decision, in which the Court placed tremendous weight on the word. "enforce" in Section 5 of the Fourteenth Amendment; ${ }^{13}$ and, on the scholarly side, Justice Scalia's selfproclaimed textuahsm in his book $A$ Matter of Interpretation. ${ }^{14}$

The question, then, is whether our present "conservative" Justices, despite their apparent textualism, are prepared to invoke unwritten law when it suits a "conservative" agenda. Shockingly, it turns out that they are. I will not even mention the Court's recent decision involving child visitation rights, ${ }^{15}$ because that case arguably is a kind of Brennan-era residue, albeit with a family-values spin, arguably unrepresentative of the current majority's pathbreaking constitutional decisions. Rather, the cases I have in mind are exemplified by Printz v. United States, ${ }^{16}$ which struck down a federal statute requiring state officers to help implement a federal gun-registration program. ${ }^{17}$

As everyone knows, the Court's opinion in Printz, written by Justice Scalia himself, expressly states that the Court's holding does not rest on the Constitution's text or original understanding, but rather

12. United States v. Lopez, 514 U.S. 549, 561 (1995) (striking down the Gun-Free School Zones Aet of 1990 on the ground that carrying guns near a school is not a "commercial" or "economic" activity).

13. City of Boerne v. Flores, 521 U.S. 507, 519 (1997) (striking down the Religious Freedom Restoration Act on the ground that it did not "enforce," but rather "altered" the meaning of the Fourteenth Amendment).

14. See ANTONIN SCALIA, A MATTER of INTERPRETATION 24 (1997) (defining what it nieans to be a textualist).

15. Troxel v. Granville, 530 U.S. 57, 75 (2000) (holding that a visitation order allowing the petitioners to visit their grandchildren was an unconstitutional infringement on the respondent's fundamental right to make decisions concerning the care, custody and control of her two daughters).

16. 521 U.S. 898 (1997).

17. Id. at 935 . 
on a principle first announced in the 1992 case of New York v. United States ${ }^{18}$ - the principle that the federal government cannot "commandeer" state legislative or executive officers in the service of federal regulatory programs. ${ }^{19}$ This anticommandeering principle is classic old-fashioned unwritten law. It is just as unwritten as the right of privacy ever was or is. To be sure, it is a question of state rights rather than individual rights, but that does not make the right any less unwritten. To put it another way, the Tenth Amendment establishes no greater textual basis for Printz and New York than the Ninth Amendment does for Roe. In other words, Printz does some serious Roeing, and hence Printz easily could puncture the illusion, if anyone ever suffered froin this illusion-and I confess I once did-that Justice Scalia was at least to be respected for his methodological integrity.

But this analysis is too easy. Of course unwritten constitutionalism of this sort is alive and well. It always has been and probably always will be. It is just too cheap to charge the current Court with inethodological cheating, particularly if you hold, as I do, that unenumerated constitutional rights are not per se illegitimate.

\section{The NEW UNWRITTEN LAW: ThE ElEventH AMENDMENT}

Let me turn, therefore, to a more subtle, more contestable, but nore important and illuminating sense in which unwritten law is in play today: the Court's fantastic Eleventh Amendment doctrine.

People do not tend to think of the Court's Eleventh Amendment cases as belonging to the same genus as Roe $v$. Wade. The reason is that the Court is engaged, or at least putatively engaged, in the imterpretation of a definite piece of constitutional text, the Eleventh Amendment. But at a certain point, of course, the fact that a court claims to be "interpreting" a clause does not render the results any less unwritten.

Ronald Dworkin once argued indignantly that there was nothing unwritten or unenumerated about Roe's right of privacy. The right of privacy, he argued, is arrived at through a standard process of textual interpretation, in which a general clause in the Constitution-there,

18. 505 U.S. 144 (1992).

19. Printz, 521 U.S. at 905,912 (stating that "there is no constitutional text speaking to this precise question" and citing, with approval, New York, 505 U.S. at 188, which invalidatcd a federal hazardous waste disposal statute). 
the Due Process Clause-is read to yield a more specific principle. ${ }^{20}$ The right of privacy is, he concluded, no more unwritten than the freedom of symbohic expression, which is similarly arrived at by interpreting the First Amendment. ${ }^{21}$

To be sure, on further review, Dworkin discovered that the true "textual home" for Roe's right was in the Religion Clauses, not the Due Process Clauses, after all, but never mind that little modification. ${ }^{22} \mathrm{Or}$, rather, do mind it, because the very term "textual home" (and that is Dworkin's phrase) communicates as clearly as one could like that we are dealing here with a classic unenumerated right-a right that amiounces or establishes itself in the first place independently of the text, and then, only afterward, comes to roost or is 10cated in its proper textual home.

Dworkin's post-hoc discovery of Roe's true textual home may seem a hittle foolish, but he is of course no fool. He was quite right to problematize the distinction between written and unwritten law. But the proper lesson to draw from this problematization is not that all the rights we previously have thought of as unenumerated are in fact simply contested interpretations of one or another piece of the constitutional text. The proper lesson is that some putative interpretations of the constitutional text-including the effort to locate the right of privacy in the Due Process Clause or, for that matter, the Religion Clauses-are so strained that they have to be regarded as excursions into unwritten constitutional law.

The Court interprets the words of the Eleventh Amendment, "any suit ... commenced ... against" a state "by Citizens of another State,",23 to mean "any suit... commenced ... against" a state "by Citizens of the same state. ${ }^{24}$ When the Court reads "citizens of another State" to mean "citizens of the same State"-when "other" is "interpreted" to mean "same," which, in case anyone has not noticed, is the opposite of "other"

20. See Ronald Dworkin, Unentmerated Rights: Whether and How Roe Should Be Overruled, 59 U. CHI. L. REV. 381, 381, 386-91 (1992) (arguing that the entire "distinction between enumerated and unenumerated rights ... is bogus").

21. Id. at 388-91.

22. Id at 419-25.

23. U.S. CONST. amend. XI (emphasis added).

24. See, e.g., Bd. of Trs. of the Univ. of Ala. v. Garrett, 531 U.S. 356, 121 S. Ct. 955, 961-62 (2001) (noting that the Court repeatedly held that the Eleventh Amendment applies to suits against a state by citizens of that state).

25. On this basis, the Court has held, for example, that if a state discriminates against its 
tion at all. What we are dealing with, obviously, is the enforcement of an unwritten principle-the principle, of course, of state sovereign immunity, which we may like or dislike, but which we should not say has its textual home in the Eleventh Amendment. In other vords, the Court should not hold that a suit by North Carohna citizens against North Carolina under federal law is barred by the Eleventh Amendment. The Court ought to say, as it practically has said already: "This suit is barred by the state's fundamental right of sovereign immunity, a right nowhere enumerated in the constitutional text but one that we are prepared to recognize and enforce just as we enforce the unwritten right of privacy recognized in Roe $v$. Wade.,"36

So the real question becomes more subtle than the one with which I began. The question is how the Court creates unwritten constitutional law around the constitutional text-within what might be called the interstices of the text.

\section{THE NEW UNWRITTEN LAW: THE FIRST AMENDMENT}

With this question in mind, let me turn to a case decided in 2000 , Boy Scouts of America v. Dale. In Boy Scouts, the Supreme Court held that a New Jersey statute forbidding discrimmation against ho-

handicapped enployees, in violation of federal law, the employees in essence have no legal remedy; their suit against the state is barred by the Eleventh Amendment. Id. at 968 . According to the Garrett majority, the individuals are not left remediless because the United States still can sue the state on their behalf. Id. at $968 \mathrm{n} .9$.

26. In a response to this Essay, Professor Vermeule says that reading the word "another" in the Eleventh Amendment to inean "the same" is merely an "ineremental move away from text." Adrian Vermeule, The Facts About Unwritten Constitutionalism: A Response to Professor Rubenfeld, 51 DUKE L.J. 473, 474 (2001). Assuming that "ineremental" is intended to mean "small" or perhaps "very small," I am a little puzzled by this reaction, given that "the same" and "another" are antonyms. I wonder whether Professor Vermeule would feel that the Justices had made only an "incremental move away from text" if they held that the Eighth Amendment prevented an individual, once prosecuted, from being tried ever again for any other crime, on the theory that the Double Jeopardy Clause bars a second prosecution for "the same offense," and "the same" is only "incrementally" reinoved from "another." Professor Vermeule suggests that it would be "absurd" to protect states from federal suits only when brought by citizens of other states. Id. But of course it is not at all absurd, if the point of the Eleventh Amendment is to bar only state-law suits against states brought under the federal courts" "diversity" jurisdietion, not federal-law suits against states brought under the federal courts" "arising under" jurisdiction, which is precisely what the Eleventh Amendment's text suggests. All this is well known in the Eleventh Amendment hiterature, and I assume Professor Vermeule knows it, too. At any rate. Professor Vermeule concedes that with Alden v. Maine, 527 U.S. 706, 711-12 (1999) (barring suits against states brought in state court), the Justices have taken a wanother step toward unwrittenness." Vermeule, supra, at 474.

27. 530 U.S. 640 (2000). 
mosexuals could not be applied constitutionally to the Boy Scouts organization, which had expelled a liomosexual scoutmaster. According to the Boy Scouts majority, New Jersey's law violated the Boy Scouts' First Amendment rights. ${ }^{28}$

Boy Scouts is another case that does not register on the constitutional radar screen as an unenumerated rights case. Boy Scouts will not be imcluded in the casebook supplement chapters about "nontextual constitutional rights" or "modern substantive due process." Boy Scouts will appear as a First Amendment case, and there is nothing more enumerated than the First Amendinent, is there?

Well, yes and no. Boy Scouts was a freedom of association case. It was the Scouts' right of association that New Jersey's statute was found to have violated. ${ }^{29}$ What is the status of this associational right-is it written or unwritten?

There are two constitutional riglits of association. The first is the right of intimate association, which applies to decisions about whom to marry, to live with, to go to bed with, and so on. ${ }^{30}$ This right does not derive from the First Amendment. It is usually seen as a subspecies of the right of privacy, and it counts as unwritten from any perspective that recognizes the distinction between written and unwritten law. ${ }^{31}$ But the right of intimate association was not at issue in Boy Scouts; the Scouts were found to be much too large an organization to engage in "intimate" association. The associational right at issue in Boy Scouts was, instead, the right of "expressive association"-the riglit to associate for the purpose of engaging in expressive activity. ${ }^{33}$ This is the associational right associated with the First Amendment, even though it is not expressly enumerated therein.

Now I have to emphasize that the important question here, at least for ine, is not whether the right of expressive association is ultimately to be called written or unwritten, enumerated or unenumerated, as if that characterization were enough to convey what to think of the Boy Scouts decision. The point, rather, is to understand some-

28. Id. at 661 .

29. Id.

30. See, e.g., Moore v. City of East Cleveland, 431 U.S. 494, 506 (1977) (invalidating an ordinance limiting the occupancy of any dwelling unit to the members of the nuclear family).

31. In Moore, the Court rested its decision on the "Due Process Clause of the Fourteenth Amendment" and cited Roe $v$. Wade, among other privacy decisions, as precedent. Moore, 431 U.S. at 512-13.

32. Boy Scouts, 530 U.S. at 646 (rejecting claim of intimate association on this ground).

33. Id. at $647-48$. 
thing about what the Court is doing with this not-quite-written right of expressive association-something reflective of a much subtler unwrittenness and of a much more fundamental alteration of existing constitutional law.

To see what I mean, we have to look more carefully at the Court's reasoning in Boy Scouts. Here's how that reasoning went. Point one: the Boy Scouts, the majority found, are counmitted to the view that homosexuality is not "morally straight." Point two: as a result, the apphication of New Jersey's law to the Boy Scouts "would significantly affect [the Scouts'] expression;","s indeed, it would force them to "send a inessage" they opposed. ${ }^{36}$ Point three: accordingly, New Jersey law had to be tested under strict scrutiny-meaning that the Scouts' "associational interest in freedom of expression [had to be set] on one side of the scale, and the State's interest on the other," with the state having to show that its interests were "coinpelling."."7 Needless to say, the Court found no such compelling justification here.

There is one hitle problem with this reasoning, and it bears on the topic of unwritten rights. Consider a simple hypothetical. Suppose that $A$ is prosecuted for failing to pay his taxes. $A$ defends himself on First Amendment grounds. He says that his sincere belief is that the federal government is not inorally straight. Not paying taxes is $A$ 's way of communicating this behef; indeed, it is the most effective way he has of communicating his viewpoint. As a result, $A$ says that the tax laws cannot be apphied constitutionally to him or, at a mimimum, that the tax laws inust pass strict scrutiny before they can be applied to him.

First Amendment law never lias applied anything like strict scrutiny to this kind of clann, nor should it. A person gets no special immunity from the tax code just because he objects to the federal government and wants to communicate this view by not paying. For better or worse, the First Amendment never lias been lield to create a constitutional right to civil disobedience.

34. Id. at 651 .

35. Id. at 656 .

36. Id. at 653 .

37. Id. at 658-59.

38. See id. at 661 ("[P]ublic or judicial disapproval of a tenet of an organization's expression does not justify the State's effort to compel the organization to acept members where such an acceptance would derogate from the organization's expressive message."). 
The objection, then, to the Court's reasoning in Boy Scouts is this: why are the Boy Scouts any different from tax protesters? The Boy Scouts want to violate a law in order to communicate a message. So do tax protesters. The Boy Scouts say that their ability to communicate a view that they sincerely and centrally hold will be significantly impaired if they are made to comply with the law. So do tax protesters. The Boy Scouts feel they will be forced to coinmunicate a deeply obnoxious message if made to obey the law. So do tax protesters. But the tax protester's clain will be dismissed. His claim gets no strict scrutiny. Why is the same not true of the Boy Scouts?

Now, incredibly simplistic though this objection is, I actually think that there is no good answer to it. The Boy Scouts were in the very same position as a tax protester. Despite all the controversy, Boy Scouts was an easy case that the Court got wrong. People are not supposed to get First Amendnient immunity just because they want to break a law for expressive purposes. ${ }^{39}$

Someone will reply, however, that the Boy Scouts and the tax protester are in coinpletely different positions. The Boy Scouts are associating; the tax protester is not. The Boy Scouts' associational choices are interfered with; the tax protester's are not. This is in fact what the Boy Scouts majority said. New Jersey's law, the Court held, "directly and immediately affects associational rights" and hence is properly subjected to strict scrutiny, ${ }^{40}$ but people like tax protesters, whose associational rights are not affected, receive much less exacting review.

Now this is a very peculiar answer, for three reasons. First, to remain with the example of the tax protester for a mionient, a tax law does "directly and immediately affect associational rights." The Court explicitly has held, in cases like Buckley $v$. Valeo, that paying money to political organizations is an act of association. ${ }^{42}$ A law forcing us to pay money to the Democratic party or to Tom DeLay's re-election campaign would immediately be seen as a direct act of compulsory association. So the Court's answer is no answer at all, at least for $A$, the tax protester. The tax laws do force an unwanted act of expressive association upon him, just as New Jersey's law, in the Court's view,

39. For a detailed analysis, see Jed Rubenfeld, The First Amendment's Purpose, 53 STAN.

L. REV. 767, 807-17 (2001).

40. Boy Scouts, 530 U.S. at 659 (emphasis added).

41. 424 U.S. 1 (1976).

42. Id. at $15-23$. 
forced an unwanted act of expressive association on the Scouts. This is just a detail, really, but not a trivial detail.

Second, every discrimination law in every application "directly and immediately" affects associational freedom and thereby "significantly affects" people's ability to communicate messages they want to communicate. Discrimination is highly expressive. That is one of its evils. It is one of the most effective means available-perhaps the most effective means-by which people can communicate their views about the relative superiority and inferiority of particular groups. The truth is that all our discrimination laws force people, precisely by dictating their associational decisions, to express a pro-equality viewpoint just as much as the Scouts were forced by New Jersey to express a pro-homosexual viewpoint.

Thus the Boy Scouts inajority's reasoning is not easy to cabin. Does a racist homeowners' association now have a First Amendment claim against laws banning discrimination in housing? If not, why not?

Finally, and most important for present purposes, the Court's answer suggests that the unenumerated right of association occupies a higher constitutional status than the First Amendment's enumerated rights themselves. Apparently, we are to understand that a tax protester suffers "merely" a burden on his freedom of speech and therefore can claim only lenient First Amendment reviev. The Boy Scouts, however, suffer an intrusion into their "associational freedom," and as a result they do get strict scrutiny.

To make this point still clearer, consider Boy Scouts in relation to Employment Division v. Smith $h^{43}$ in free exercise doctrine. Boy Scouts essentially resuscitates the Sherbert $v$. Verner" ${ }^{4}$ regime repudiated by $\mathrm{Smith}^{45}$ only it does so for the right of association rather than for the free exercise of religion. Smith holds that a law of general applicability does not trigger strict scrutiny just because it happens to impinge on sonreone's religious practices. ${ }^{46}$ Boy Scouts says that if a law of general apphicability happens to impinge directly on someone's asso-

43. 494 U.S. 872 (1990).

44. 374 U.S. 398 (1963) (applying strict scrutiny to a Seventh-Day Adventist's claim that her free exercise rights were burdened by a denial of her unemployment benefits, when her firing was due to her refusal to work on a Saturday).

45. Smith, 494 U.S. at $884-85$.

46. Id at $876-82$. 
ciational choices, then it does generate strict scrutiny. ${ }^{47}$ So Boy Scouts indicates not only that an unenumerated right of association finds a textual home between the lines of the First Amendment, but that this unwritten right is of a higher constitutional status, commanding greater constitutional scrutiny, than the rights actually enumerated there.

In other words, Boy Scouts may not look like Roe on its face, but it turns out to out-Roe Roe itself. Not only does Boy Scouts recognize an unwritten right, but it elevates this unwritten right above the written ones. This is championship Roeing-gold-medal Roeing.

\section{THE NEW UNWRITTEN LAW: "BALANCING" TESTS}

But now I will push this analysis still further-and this time, I am afraid, even fewer will agree with its conclusions. Consider now the Court's affirmative action cases, such as Adarand Constructors, Inc. $v$. $P e n a,{ }^{48} \mathrm{~m}$ which the Court held that governmental racial preferences must be tested under strict scrutiny. ${ }^{49}$ The reasoning in these cases, surprisingly, is closely linked to the reasoning in the Boy Scouts decision. Here is how.

Just as in Boy Scouts, Adarand mstructs that a strict scrutiny balancing test must be applied to test whether a putative constitutional injury is outweighed or justified by sufficiently compelling state interests. Accordmg to the Court in Adarand, "whenever the government treats any person unequally because of his or her race, that person has suffered an injury that falls squarely within the language and spirit of the Constitution's guarantee of equal protection."s0 But violating "the language and spirit" of the equal protection guarantee is not necessarily unconstitutional. "The application of strict scrutiny, in turn, determines whether a compelling governmental interest justifies the infliction of that injury."

Now, the principle of color blindness enunciated by Justice O'Connor in Adarand is not stated expressly in the equal protection guarantee to which the Court refers. Nor, with all due respect to Justices Scalia and Tliomas, who claim to be both textualists and originahists, can this principle of color blindness find support in the origi-

47. Boy Scouts, 530 U.S. at 659.

48. 515 U.S. 200 (1995).

49. Id. at 226-27.

50. Id. at 229-30.

51. Id. at 230 . 
nal understanding of the text. On the contrary, the very Congress that framed and promulgated the Fourteenth Amendment repeatedly passed laws directing special governmental benefits to blacks-not merely to "freedmen," but specifically to "colored" people." In other words, while the Fourteenth Amendment obviously was understood to abohsh various kinds of discrimination against blacks, the best evidence we have of the original understanding indicates that the use of racial classifications to allocate special governmental benefits in favor of blacks was viewed as permissible.

So what is the status, then, of this principle of color blindness, this right not to be treated unequally on the basis of race, which cannot be found in the text or original understanding of the Fourteenth Amendinent? Is it written or unwritten?

Trying to answer this question is not helpful. Call it an instance of interstitial unwritten law-unwritten law in the mterstices of the constitutional text. What requires attention is how the Court is deploying these interstitial unwritten rights-the right of expressive association in Boy Scouts, the right not to be treated unequally on the basis of race in Adarand-im order to effect a fundamental, but unwritten, structural change in constitutional doctrine, a change to which professional constitutional spectators are not paying nearly enough attention.

Here is what I mean. It has to do with strict scrutiny. As everyone knows, strict scrutiny emerged in equal protection doctrine in connection with the idea of suspect classes. Strict scrutiny applies, the Court used to say, "only" to a law that "operates to the peculiar disadvantage of a suspect class." ${ }^{153}$ But affirmative action laws do not "operate to the peculiar disadvantage of a suspect class." They do the opposite. As a result, today's strict scrutiny doctrine can no longer be organized, and is no longer organized, around the concept of suspect classes. It is organized instead around the concept of suspect classifications-a momentous, if often unnoticed, shift.

A racial classification triggers strict scrutiny, regardless of whether it "operates to the peculiar disadvantage of a suspect class." That is the rule unequivocally einbraced by Adarand. But why exactly? Why does affirmative action trigger strict scrutiny if it advan-

52 See Jed Rubenfeld, Affirmative Action, 107 YALE LJ. 427, 430-31 (1997) (discussing the position taken by the strict constructionalists on affirmative action).

53. E.g., Mass. Bd. of Ret. v. Murgia, 427 U.S. 307, 312-13 (1976) (ciling, with approval, San Antonio Indep. Sch. Dist. v. Rodriguez, 411 U.S. 1, 16 (1973)). 
tages, rather than disadvantages, members of a suspect class? The reason repeatedly given by the Justices is that the unintended consequences of affirmative action's racial classifications are too pernicious to be permitted without compelhng justification. For example: "racial paternalism and its unintended consequences can be as poisonous and pernicious as any other form of discrimination. So-called 'benign' discrimination teaches many that because of chromic and apparently immutable handicaps, minorities cannot compete with them without their patronizing indulgence. ${ }^{, 54}$ Or agam: "we subject racial classifications to strict scrutiny precisely because that scrutiny is necessary to determine whether they are benign ... or wliether they misuse race and foster harmful and divisive stereotypes witlout a compelling justification." 55

But this reasoning, this shift from suspect classes to suspect classifications, yields in turn a transformation in the function and use of strict scrutiny. In suspect-class analysis, the focus is on invidious purpose-tlie purpose, for example, of harming or subordinating a racial minority, or communicating their lower caste-like status; strict scrutiny is understood as a ineans of smoking out, or as John Hart Ely put it twenty years ago, "flushing out," such invidious purposes. ${ }^{36}$ The Court used to embrace this concept of strict scrutiny expressly, holdmg that strict scrutiny in race cases was necessary to "smoke out" the laws that were "in fact motivated by illegitimate notions of racial inferiority.",57

But the Adarand Court embraced a very different picture of strict scrutiny: a cost-benefit, balancing-test, justificatory picture, in which strict scrutiny tests whetler the state's interests outweigh and justify an asserted constitutional injury. ${ }^{58}$ The Court had to embrace this picture, because nobody believed or alleged that the federal government's small-business minority set-aside program was "in fact motivated by illegitimate notions of racial inferiority." As noted a mo-

54. Adarand, 515 U.S. at 241 (Thomas, J., concurring).

55. Bush v. Vera, 517 U.S. 952,984 (1996) (plurality opinion).

56. See JOHN HART ELY, DEMOCRACY AND DISTRUST 146 (1980) ("[S]pecial scrutiny, in particular its demand for an essentially perfect fit, turns out to be a way of 'flushing out' unconstitutional motivation....").

57. City of Richmond v. J.A. Croson Co., 488 U.S. 469, 493 (1989) (plurality opinion).

58. See Adarand, 515 U.S. at 230 ("The application of strict scrutiny, in turn, determines whether a compelhing governmental interest justifles the infliction of [the constitutional] injury.").

59. Croson, 488 U.S. at 493. 
ment ago, the Justices' claim is rather that the unintended consequences of affirmative action potentially are so harmful as to require strict scrutiny.

To summarize, suspect-classification strict scrutiny responds to unintended harms, while suspect-class strict scrutiny is trying to get at intentional harms. Classificationism produces cost-benefit, justificatory strict scrutiny. Suspect-class analysis produces smoking-out, purposivist strict scrutiny.

Observe that the very same transformation describes precisely what is taking place in Boy Scouts. In the landmark First Amendment association cases, mvolving the NAACP in the South in the 1950s and 1960 s, the Court apphed a version of strict scrutiny, and this made perfect purposivist sense; the circumstances strongly suggested an impermissible state purpose, and strict scrutiny with its classic narrowtailoring requirement served to smoke out this purpose-i.e., the purpose of targeting the NAACP or its members precisely because of their First Amendinent activities (the petitioning they were doing, the lawsuits they were bringing, the speeches they were making, and the viewpoints they were commumicating). ${ }^{60}$

By contrast, strict scrutiny in a case like Boy Scouts has nothing to do with smoking out anything. There is no suggestion that New Jersey was trying to target the Boy Scouts because of its First Amendment activity or that applying strict scrutiny to New Jersey's law was necessary to sinoke out some other impermissible purpose. Instead, strict scrutiny is understood to be applicable only because a very different version of strict scrutiny has been embraced-the costbenefit, balancing-test version.

In other words, below the surface of constitutional doctrine, a considerable change is taking place. Heightened scrutiny is today the chief doctrinal tool for exercising the power of constitutional judicial review. It makes a great deal of difference whether the smoking-out conception of strict scrutimy is adopted or the cost-benefit conception. Cases such as Adarand and Boy Scouts turn on this issue. Yet this fundamental transformation in the doctrime is unwritten: the shift from suspect classes to suspect classifications never is acknowledged

60. See, e.g., NAACP v. Button, 371 U.S. 415,444 (1963) (holding that a state law expanding the scope of malpractice in a way that prejudiced the NAACP was unconstitutional); NAACP v. Alabama, 357 U.S. 449, 462-63 (1958) (holding that the NAACP did not have to provide Alabama with its membership lists). 
or explained in the case law, nor is the shift from smoking-out strict scrutiny to cost-benefit strict scrutiny.

This unacknowledged shift in constitutional doctrine introduces a new and especially dangerous kind of unwrittenness into constitutional law. How is the Court supposed to decide whether the benefits of a law banning discrimination on the basis of sexual orientation "outweighs" the burdens such a law places on associational interests? I can tell you how the Court reasoned its way through this problem in Boy Scouts-it did not.

After reaching the conclusion that a strict-scrutiny balancing test would have to be apphied to New Jersey's law, the Court simply struck down the law. Astomishingly, there is not a sentence or indeed a single word explaining why the scales tipped in favor of the Scouts, rather than the other way. There is only the Court's raw conclusion. The actual, decisive bit of "reasoning," if reasoming is the proper word for it, necessary to produce the ultimate holding in the casethat the Boy Scouts' expressive interests outweigh the state's interest in prohibiting discrimination against homosexuals-simply does not appear in the opinion.

But really, what nore could the Court have said? Balancing tests- of the kind that the Court now uses to strike down laws in cases like Adarand and Boy Scouts-are not susceptible to reasoned analysis. In the absence of incredibly sophisticated empirical knowledge, which the Court manifestly cannot claim, judgments in cases like Adarand or Boy Scouts about whether the scales tip one way or the other cannot be intelligibly written up or written about. They can neither be explained nor criticized in reasoned terms. Balancing tests in constitutional law operate below the surface of reason, between or outside the lines of reasoned opinion writing.

In the old unwritten law cases, like the Roe $v$. Wade privacy decisions, the unwritten right is at least expressly set forth and defended in writing. The lex non scripta always was this way; the assertedly unwritten law always was expressed and elaborated in judicial reasoning. The Rehnquist Court's new unwritten law takes unwrittenness a step further. It not only eschews the necessity of enacted text, it also dispenses with the necessity-perhaps even the possibility-of written judicial reasoning.

Say that a court strikes down racial preferences under a balancmg-test version of strict scrutiny. The court holds that remedying societal discrimination is not a sufficiently compelling state interest to justify affirmative action. On what ground could suclı a conclusion be 
supported? On what ground criticized? No articulable reasoning can be brought into play here. There is ouly a normative conclusion, presented in the form of a balancing of interests.

Once the question in Boy Scouts is determined to be whether the benefits of a law banning discrimination on the basis of sexual orientation outweigh the burdens, argument drops out of the picture. Reason drops out. All that is left, as the Court's opinion so vividly demonstrates, is a judicial say-so. This is the new unwritten constitutional law, with which we need to be much more concerned. 
$* * *$

HeinOnline -- 51 Duke L.J. 306 2001-2002 